\title{
AGRIBUSINESS CHANGES CAUSED \\ BY THE RUSSIAN FOOD EMBARGO: AN INTERFIRM RELATIONSHIPS PERSPECTIVE
}

\section{PROMJENE U AGROBIZNISU UZROKOVANE EMBARGOM NA RUSKU HRANU: PERSPEKTIVA MEĐUSOBNIH ODNOSA MEĐU PODUZEĆIMA}

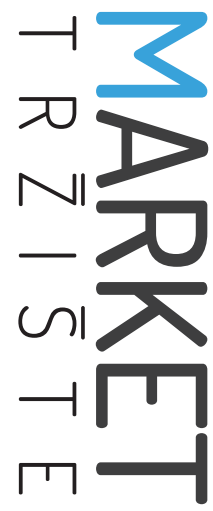

Market-Tržište

Vol. 33, No. 1, 2021, pp. 7-24

UDK 338.439.5:339.545(470)

DOl http://dx.doi.org/10.22598/mt/2021.33.1.7

Original scientific paper

\begin{abstract}
Olga A. Kusraevaa, Vera A. Rebiazinab
a National Research University Higher School of Economics, 20 Myasnitskaya ulitsa, 101000 Moscow, RUSSIA, e-mail: okusraeva@hse.ru

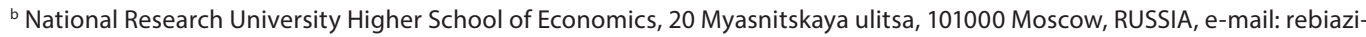
na@hse.ru
\end{abstract}

\begin{abstract}
Purpose - The objective of this paper is to identify the main directions of changes in Russian agribusiness caused by the food embargo through the lens of interfirm relationships.

Design/Methodology/Approach - Qualitative research in the form of a focus group was conducted. The sample consisted of nine senior management representatives of Russian agribusinesses.

Findings and implications - The study revealed that the Russian food embargo contributed to the development of interfirm relationships in Russian agribusiness. Both retailers and producers tend to use a relational approach and develop interfirm relationships in order to build sustainable value chains and long-term relationships with partners. The resulting conclusions represent important changes in interfirm relationships between different actors in Russian agribusiness: (1) retailers tend to interact with providers for the purpose of building sustainable value chains; (2) at the same time, the
\end{abstract}

\section{Sažetak}

Svrha - Cilj je rada otkriti glavne smjerove promjena u ruskom agrobiznisu uzrokovane prehrambenim embargom kroz prizmu odnosa među poduzećima.

Metodološki pristup - Provedeno je kvalitativno istraživanje metodom fokus grupe. Uzorak se sastojao od devet predstavnika višega menadžmenta iz ruskih agrobiznisa.

Rezultati i implikacije - Istraživanje je otkrilo da je embargo na rusku hranu pridonio razvoju odnosa među poduzećima u ruskom agrobiznisu. I trgovci na malo i proizvođači nastoje koristiti relacijski pristup te razvijati međusobne odnose kako bi izgradili održive lance vrijednosti i dugoročne partnerske odnose. Dobiveni zaključci predstavljaju važne promjene u odnosima među poduzećima, između različitih aktera u ruskom agrobiznisu: (1) trgovci imaju namjeru interakcije s dobavljačima radi izgradnje održivih lanaca vrijednosti; (2) istodobno se postupno mijenjaju kriteriji koje trgovci na malo postavljaju svojim dobavljačima. 
criteria retailers impose on their suppliers are changing gradually.

Limitations - The limitations of the study are related primarily to the method used. Data collected from the focus group are not statistically representative of the entire Russian agribusiness. Additional research beyond this exploratory qualitative study is needed to test the assumptions and generalize the results.

Originality - In the context of B2B marketing research, this study is the first to address changes in the value chain in the Russian food market. An analysis of the balance of power among its key players shows that the food embargo has challenged the structure of the Russian food market. The resulting changes in the criteria for building interfirm relationships have been dramatic for both suppliers and producers.

Keywords - agribusiness, embargo, interfirm relationships, emerging markets, Russia
Ograničenja - Ona su prije svega povezana s primijenjenom metodom. Podaci dobiveni od fokus grupe nisu statistički reprezentativni za cjelokupni ruski agrobiznis. Potrebno je dodatno istraživanje uz ovo eksplorativno kvalitativno istraživanje kako bi se provjerile pretpostavke i generalizirali rezultati.

Doprinos - $U$ okviru istraživanja poslovnoga tržišta (B2B), ovo je prvo istraživanje usmjereno na promjene $u$ lancu vrijednosti na ruskom tržištu hrane. Analiza odnosa snaga između ključnih igrača pokazuje kako je embargo na hranu izazvao promjenu strukture ruskog tržišta hrane. Promjene u kriterijima za izgradnju odnosa među poduzećima dramatične su i za trgovce i za proizvođače.

Ključne riječi - agrobiznis, embargo, odnosi među poduzećima, tržišta u nastajanju, Rusija 


\section{INTRODUCTION}

Internationally, an embargo is a fairly common form of economic sanctions. A complicated global political situation and the different positions taken on various international issues by Russia and European Union (EU) countries in 2014 resulted in the introduction of Western sanctions against the Russian Federation. In response, Russia curbed the import of certain food products, raw materials, and agricultural goods from EU countries, the United States, Canada, Australia, and Norway. The food embargo was imposed against the majority of Russian strategic suppliers of agricultural products who had adequate infrastructure and an adjusted logistics system.

In the 2000s, the level of integration among agricultural producers, processing enterprises, and retail chains remained low (Agroindustrial complex scientific and technological development..., 2016). This was true both of the regions considered separately and Russia as a whole. Over time, the business and the academic community ceased to consider vertical integration an optimal solution for creating a single organization in agribusiness. Attention shifted gradually towards interfirm relationships and a network organization. However, as the switch was quite slow during the 2000s, a decade later, relationships still remained poorly developed. Despite the fact that geographical boundaries are being erased, with this trend clearly mirrored in the agricultural sector, sustainable long-term partnerships are a relative rarity in the agribusiness (Usova, 2014).

The establishment of integrated relationships in the spheres of production, processing, and marketing of agricultural products based on equal partnerships was highlighted as an important course even before the introduction of the food embargo against Russia'. However, the embargo changed the established patterns which characterize the way Russian agribusiness works, so full functioning became impossible. Companies were forced to build their activities in accor- dance with the changes emerging as a result of the embargo.

The current literature on embargoes focuses on their political, social, or economic consequences (Coulibaly, 2009; Günçavdi \& Küçükçifçi, 2009). Extant studies are quite fragmented, making generalization hardly possible. In addition, a special interest in such research has emerged only in the past few years, that is, since the introduction of the Russian food embargo (Wengle, 2016). Therefore, a lack of studies on the impact of the food embargo does not allow researchers to form a view on the features that characterized the relationships among agribusinesses prior to the introduction of the food embargo. This study fills a significant research gap regarding changes in marketing functions and interfirm relationships in countries involved in the embargo.

The purpose of this paper is to reveal the main directions of changes in Russian agribusiness caused by the food embargo through the lens of interfirm relationships. To achieve this objective, qualitative research was conducted through focus group discussions involving nine representatives of Russian agribusiness.

The paper is organized as follows: First, the study introduces some theoretical background concerning previous research on the impact of embargoes, specific features of Russian agribusiness, and development of interfirm relationships. This is followed by a short review explaining the methodology of the research and providing a description of the respondents. The results of the empirical research study of changes in relationships between agribusiness firms are presented in the third part.

\section{THEORETICAL REVIEW}

\subsection{Previous studies on the impact of embargoes}

The introduction of embargoes significantly affects the economies of different countries either directly or indirectly. In terms of international 


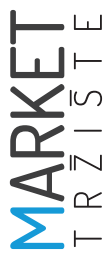

trade policies, an embargo can be defined as a prohibition or restriction of economic relations imposed by one or several sender countries on a target country (Davis \& Engerman, 2003).

Researchers distinguish between two types of this form of economic sanction: trade and financial. A trade embargo means full or selective prohibition or restriction of trade relations with the object of the sanctions (a total or partial embargo). A financial embargo is defined as a full or selective ban or restriction on financial relations with the object of the sanctions. Such restrictions apply to investments, financial transactions, provision of economic assistance, grants, loans, or consist in freezing the assets of the government, businesses, or individuals.

Most researchers examine the phenomenon of embargo on the basis of trade policies. Table 1 describes some examples of embargoes and illustrates the consequences of their introduction. The cases presented in the table include only the embargoes that are still in force. A research study exploring the 1974 embargo against Iran emphasizes the political reasons for such a measure, which led Iran to search for new markets and forced Iranian companies to seek new partners. However, despite economic losses in the short term and due to the strategic importance of Iranian oil and its simple transportation, it was not difficult to replace partners. A few years after the embargo was imposed, Iran was able to sell the same amount of oil as prior to its introduction.

The embargo against Northern Cyprus led the country to almost total dependence on Turkey for political and economic support. From that point on, Turkey became Northern Cyprus' key partner in trade and the only link to the rest of the country. Because of this, the structure of the economic activities in Northern Cyprus changed significantly, and service sectors became the main source of income for the Northern Cypriot economy.

It is obvious that in the case of China, embargoes cannot be regarded as the main reason for the current high level of the country's economic development. However, researchers argue that the embargo imposed on China in 1989 acted as a stimulus. The embargo accelerated the decision-making process concerning the development of some industries that were experiencing difficulties because of the embargo. Nowadays, these industries not only meet domestic demand but also have sufficient output for export (for example, in February 2017, Russia imported USD 2 billion worth of goods from China (Bolgova, 2017)).

It is too early to talk about the long-term consequences of the food embargo in the case of Russia. However, a shift in the government policy towards import substitution is clear. This change led to stronger support for Russian agribusiness on legal and economic issues while also helping increase the number of Russian companies engaged in agribusiness.

An outstanding line of research concerning the 1961 United States' embargo against Cuba by deals with the influence of the embargo on the state of health and professional conditions of Cubans. A gradual normalization in relations which followed the conflict between Cuba and the United States has been under way since the middle of 2013. But he U.S. embargo against Cuba, which is still in effect, has inflicted losses of around USD 125.9 billion on the Cuban economy (Gordeev, 2016). However, research shows that, since 1994, Cuba has become an attractive investment ground for foreign capital due to the low cost of skilled and educated workforce.

The food and medicine embargo on Cuba, introduced in 1961 and officially lifted only in 1999, caused widespread malnutrition and disease among Cubans and prompted 3,000 doctors to leave the country. Compensation for this loss was achieved through the reorganization of medical education. In 2007, the medical profession was the most popular profession in Cuba, with about 70,000 certified doctors tending to a population of about 11 million people. In 2012, the World Health Organization officially recognized Cuban medicine as the best in the world. 
TABLE 1: Characteristics and impact of embargoes

\begin{tabular}{|c|c|c|c|c|c|}
\hline & $\begin{array}{c}\text { Embargo against } \\
\text { Cuba }\end{array}$ & $\begin{array}{l}\text { Embargo against } \\
\text { Northern Cyprus }\end{array}$ & $\begin{array}{c}\text { Embargo } \\
\text { against Iran }\end{array}$ & $\begin{array}{l}\text { Embargo } \\
\text { against China }\end{array}$ & $\begin{array}{c}\text { Embargo against } \\
\text { EU countries, } \\
\text { the US, Canada, } \\
\text { Australia, and } \\
\text { Norway }\end{array}$ \\
\hline $\begin{array}{l}\text { Sender } \\
\text { countries }\end{array}$ & United States & $\begin{array}{l}\text { All countries } \\
\text { except Turkey }\end{array}$ & EU, USA, China & EU, USA & Russia \\
\hline $\begin{array}{l}\text { Target } \\
\text { countries }\end{array}$ & Cuba & Northern Cyprus & Iran & China & $\begin{array}{l}\text { EU, the U.S., Canada, } \\
\text { Australia, and } \\
\text { Norway (from } 2015 \\
\text { Albania, Montenegro, } \\
\text { Switzerland, } \\
\text { Japan, Iceland, and } \\
\text { Liechtenstein) }\end{array}$ \\
\hline $\begin{array}{l}\text { Objects of } \\
\text { embargo }\end{array}$ & $\begin{array}{l}\text { All trade and } \\
\text { financial contracts } \\
\text { with the target } \\
\text { country }\end{array}$ & $\begin{array}{l}\text { All trade and } \\
\text { financial contracts } \\
\text { with the target } \\
\text { country }\end{array}$ & $\begin{array}{l}\text { All trade in } \\
\text { fungible crude } \\
\text { oil with the } \\
\text { target country, } \\
\text { investments and } \\
\text { loans }\end{array}$ & \begin{tabular}{|l|} 
All types of \\
contracts with \\
the target country \\
and loans from \\
all international \\
financial \\
organizations
\end{tabular} & $\begin{array}{l}\text { Imports of particular } \\
\text { goods from the } \\
\text { target countries }\end{array}$ \\
\hline Imposed in & 1961 & 1974 & 1979 & 1989 & 2014 \\
\hline $\begin{array}{l}\text { Authors, } \\
\text { years }\end{array}$ & $\begin{array}{l}\text { Campion and } \\
\text { Morrissey, 2013; } \\
\text { Cuellar, } 2015\end{array}$ & $\begin{array}{l}\text { Günçavdi and } \\
\text { Küçükçifçi, 2009; } \\
\text { Balcilar, Kutan, and } \\
\text { Yaya, } 2017\end{array}$ & $\begin{array}{l}\text { Torbat, 2005; } \\
\text { Patterson, } 2013\end{array}$ & $\begin{array}{l}\text { Sachdeva, 2014; } \\
\text { Grosse, } 2014\end{array}$ & Wengle, 2016 \\
\hline $\begin{array}{l}\text { Type of } \\
\text { embargo }\end{array}$ & $\begin{array}{l}\text { Trade and financial } \\
\text { embargo }\end{array}$ & $\begin{array}{l}\text { Trade and financial } \\
\text { embargo }\end{array}$ & $\begin{array}{l}\text { Trade and } \\
\text { financial embargo }\end{array}$ & $\begin{array}{l}\text { Trade and } \\
\text { financial embargo }\end{array}$ & Trade embargo \\
\hline $\begin{array}{l}\text { Short-term } \\
\text { impact }\end{array}$ & $\begin{array}{l}\text { For Cuba: } \\
\text { loss of income in } \\
\text { the tourism sector; } \\
\text { increase in the } \\
\text { domestic price of } \\
\text { food and medical } \\
\text { services }\end{array}$ & $\begin{array}{l}\text { For Northern } \\
\text { Cyprus: } \\
\text { decrease in the } \\
\text { share of the } \\
\text { tradable sector' in } \\
\text { GDP; } \\
\text { adoption of the } \\
\text { Turkish lira as the } \\
\text { national currency; } \\
\text { high level of } \\
\text { dependence on } \\
\text { imports from } \\
\text { Turkey }\end{array}$ & $\begin{array}{l}\text { For Iran: } \\
\text { increase in oil } \\
\text { storage costs; } \\
\text { increase in } \\
\text { transactional } \\
\text { costs; } \\
\text { increase in the } \\
\text { domestic price } \\
\text { of oil }\end{array}$ & \begin{tabular}{|l|} 
For China: \\
development \\
of the remote \\
regions of China; \\
growing trade \\
channels between \\
Russia and China
\end{tabular} & $\begin{array}{l}\text { For Russia: } \\
\text { increase in domestic } \\
\text { prices of food; } \\
\text { active government } \\
\text { support of } \\
\text { agribusiness; } \\
\text { growing trade } \\
\text { channels with new } \\
\text { partners }\end{array}$ \\
\hline $\begin{array}{l}\text { Long-term } \\
\text { impact }\end{array}$ & $\begin{array}{l}\text { For Cuba: } \\
\text { expanding the } \\
\text { geography of } \\
\text { sustainable } \\
\text { partnerships; } \\
\text { development } \\
\text { of own } \\
\text { pharmaceutical } \\
\text { industry; } \\
\text { switching priorities } \\
\text { to the Asian region } \\
\text { and the EU }\end{array}$ & $\begin{array}{l}\text { For Northern } \\
\text { Cyprus: } \\
\text { non-tradable } \\
\text { economic } \\
\text { activities }^{2} \text { as the } \\
\text { main income- } \\
\text { generating sectors } \\
\text { in trading with } \\
\text { Turkey or other } \\
\text { countries via } \\
\text { Turkey; fewer } \\
\text { opportunities for } \\
\text { trade generating } \\
\text { international } \\
\text { liquidity }\end{array}$ & $\begin{array}{l}\text { For Iran: } \\
\text { new strategic } \\
\text { partners for } \\
\text { technologies }\end{array}$ & \begin{tabular}{|l|} 
For China: \\
active \\
development of \\
various industries, \\
including \\
agriculture, \\
resulting in the \\
coverage of \\
domestic demand
\end{tabular} & - \\
\hline
\end{tabular}


The Russian food embargo is an example of a trade embargo which refers to restrictions on consumer goods. The embargo reduced the volume of supply in the domestic market and naturally led to price increases. The growth of domestic prices in turn increased considerably the profitability of domestic food products. Industries and companies investing in capacity expansion until 2014 or unloading capacity were able to expand production.

Western supplies were partially replaced by supplies from other countries (beef from Brazil, apples from Serbia, dairy products from Belarus, etc.). At the same time, domestic products began to occupy much more space in the consumer baskets of Russians than they did before the embargo. For example, the share of non-seasonal vegetables grown in Russian greenhouses was 45\% in 2015 - 1.5 times higher than in the previous year. These circumstances directly affected competition in the Russian food market.

Before the Russian food embargo was introduced, the main countries supplying Russia with cattle meat, fish, dairy products, and cheese were EU countries, the U.S., and Canada. All the Russian food suppliers were split into four groups: (1) companies from the countries later banned by the Russian food embargo; (2) producers from the CIS countries; (3) companies from distant foreign countries; and (4) Russian producers. All the suppliers delivered goods directly to Russia. However, following the introduction of the food embargo, the composition of the main suppliers to Russia changed immediately.
As a result of the food embargo, Russian producers found themselves facing tougher competition than they did before the embargo. As the leading brands from the banned countries began to flow in through the CIS countries, they continued to compete with Russian products due to high consumer loyalty. Companies from the CIS countries and distant foreign countries began to develop brands especially for the Russian market, supporting them with marketing communication and point-of-sale activities. As competition among Russian domestic companies increased, so did the quality of their products, which included local, federal, and private brands. Furthermore, branded points of sale developed their brands' communication offline and online. Thus, owing to the appearance of new players, the rapid development of their positions and brand creation, as well as enhanced communication support, it is relevant to mention that competition became increasingly tougher than before the embargo.

Since Russia was a key market for certain countries in terms of specific products, the embargo also affected the economy of the target countries. In a report published in July 2016, the French Research Center in International Economics (CEPII) estimated export losses of 37 countries that supported sanctions against Russia at more than USD 60 billion from August 2014 to July 2015.

Despite the large number of empirical studies that have explored the impact of embargoes, there is still a lack of research into how embar-

FIGURE 1: Graphic model of the interaction between main players in the Russian food market

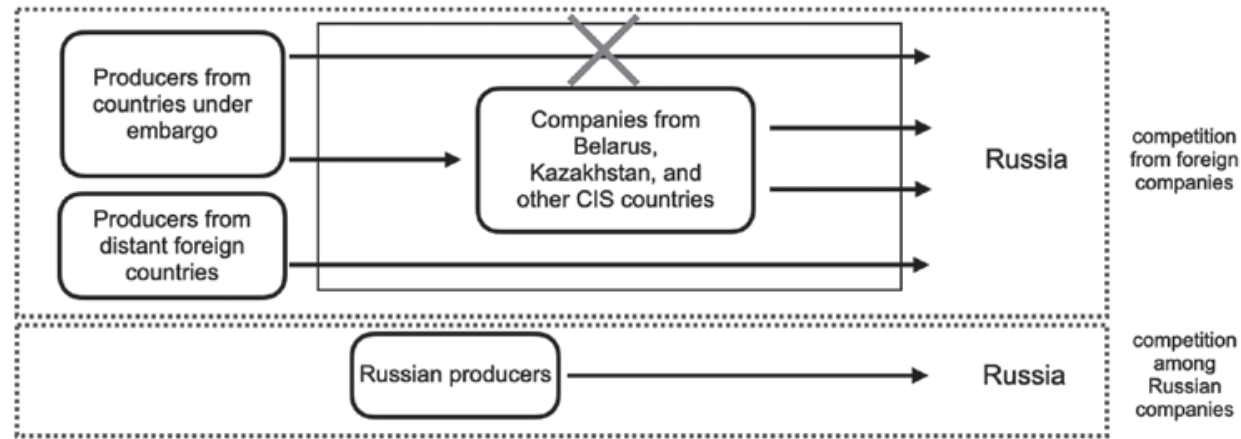


goes influence marketing and relationship management. While previous research has focused on the impacts of embargoes on target countries, this paper focuses on the impact on Russia, as the sender country of the food embargo. This is not by chance, because Russia was highly dependent on banned products in 2014, so the Russian food market suffered substantially as a result. Therefore, the impact of the Russian food embargo on the sender country (Russia) was likely equal to the impact of the embargoes on the target countries. Thus, despite Russia being the sender country, the fact that the Russian food embargo influenced interfirm relationships seems worthy of focusing the attention on Russian companies.

As the present study investigates the changes brought about in Russian agribusiness by the food embargo, we present three research questions. RQ1 is: How have food retailers and producers changed their value chains because of the Russian food embargo?

\subsection{Developing interfirm relationships: evidence from Russia}

The role of relationship marketing and interfirm relationships in enhancing the competitiveness of firms and the national economy has been highlighted in various studies (Anderson, Håkansson \& Johanson, 1994; Achrol, 1997; Uzzi, 1997; Achrol \& Kotler, 1999; Håkansson \& Ford, 2002), but mostly using the example of developed economies. Although emerging markets represent a significant part of the world economy and their share has a tendency towards expansion, they have been examined thoroughly to date. Specifically, Russia seems to be avoided in the overall academic discussion. Existing research on Russia can be described as fragmentary in that it captures only some aspects of the transformation process. The results of the interfirm relationship analysis in the Russian context are presented in Table 2.

TABLE 2: Results of interfirm relationship analysis in the Russian context

\begin{tabular}{|l|l|l|l|}
\hline \multicolumn{1}{|c|}{$\begin{array}{c}\text { Author(s), } \\
\text { year }\end{array}$} & \multicolumn{1}{c|}{$\begin{array}{c}\text { Focus of the } \\
\text { study }\end{array}$} & Method and data & \multicolumn{1}{c|}{ Contribution } \\
\hline $\begin{array}{l}\text { Halinen \& Salmi, } \\
2001 \\
\text { Proceedings of } \\
\text { the 17th IMP } \\
\text { Conference }\end{array}$ & $\begin{array}{l}\text { Personal relations } \\
\text { as a driver of } \\
\text { development in } \\
\text { business relations }\end{array}$ & $\begin{array}{l}\text { Case analysis } \\
\text { in service industries, } \\
\text { high-tech and } \\
\text { traditional } \\
\text { manufacturing }\end{array}$ & $\begin{array}{l}\text { In business relations, personal } \\
\text { relations can be enablers for } \\
\text { relationship development and } \\
\text { change forces leading to change in } \\
\text { the relationship stage. }\end{array}$ \\
\hline $\begin{array}{l}\text { Radaev, 2003 } \\
\text { Proceedings } \\
\text { of the CEPR/ } \\
\text { WDI Annual } \\
\text { International } \\
\text { Conference } \\
\text { on Transition } \\
\text { Economies }\end{array}$ & $\begin{array}{l}\text { Trust in economic } \\
\text { relations in the } \\
\text { Russian low- } \\
\text { trust transitional } \\
\text { market }\end{array}$ & $\begin{array}{l}\text { Standardized survey } \\
\text { and in-depth } \\
\text { interviews }\end{array}$ & $\begin{array}{l}\text { Formal rules are subject to intense } \\
\text { informalization. In order to confront } \\
\text { the high level of opportunism, private } \\
\text { contract enforcement methods are } \\
\text { imposed, as are closed business }\end{array}$ \\
$\begin{array}{l}\text { Business Ethics: } 2003 \\
\text { A European } \\
\text { Review }\end{array}$ & $\begin{array}{l}\text { Trust and } \\
\text { personal relations } \\
\text { in Western- } \\
\text { invested strategic } \\
\text { alliances in Russia }\end{array}$ & $\begin{array}{l}\text { Semi-structured } \\
\text { interviews of } \\
\text { Western and Russian } \\
\text { staff (17 Western } \\
\text { organizations) in } \\
1996 ; \text { a case study of } \\
\text { a Western company } \\
\text { operating in Russia, } \\
\text { conventions substitute formal } \\
\text { institutions. }\end{array}$ & $\begin{array}{l}\text { In strategic alliances developed } \\
\text { in Russia, trust is increased by } \\
\text { functional competence transfer and } \\
\text { interpersonal relations rather than by } \\
\text { monitoring and responsibility transfer. } \\
\text { Competence determinants and } \\
\text { motives are positively correlated with } \\
\text { trust, while outgroup and monitoring } \\
\text { are negatively correlated. }\end{array}$ \\
\hline
\end{tabular}




\begin{tabular}{|c|c|c|c|}
\hline $\begin{array}{c}\text { Author(s), } \\
\text { year }\end{array}$ & $\begin{array}{c}\text { Focus of the } \\
\text { study }\end{array}$ & Method and data & Contribution \\
\hline $\begin{array}{l}\text { Salmi, } 2004 \\
\text { Proceedings of } \\
\text { the 20th IMP } \\
\text { Conference }\end{array}$ & $\begin{array}{l}\text { Institutional } \\
\text { change forces } \\
\text { (i.e., formal } \\
\text { and informal } \\
\text { rules) and } \\
\text { their influence } \\
\text { on network } \\
\text { structures }\end{array}$ & Conceptual paper & $\begin{array}{l}\text { New economic paradigm led to } \\
\text { improved social relations in business, } \\
\text { along with an increase in corruption. } \\
\text { Institutional rules for behavior evolve } \\
\text { in business networks. }\end{array}$ \\
\hline \begin{tabular}{l|} 
Jansson, \\
Johanson \& \\
Ramström, 2007 \\
Industrial \\
Marketing \\
Management
\end{tabular} & $\begin{array}{l}\text { Institutional } \\
\text { influence on } \\
\text { the major } \\
\text { characteristics of } \\
\text { companies }\end{array}$ & $\begin{array}{l}\text { Conceptual paper. } \\
\text { The transition to the } \\
\text { post-Soviet era }\end{array}$ & $\begin{array}{l}\text { Different institutional context } \\
\text { defines business strategy design and } \\
\text { implementation. Different aspects } \\
\text { of strategic orientation such as } \\
\text { performance, suspicion, and patience } \\
\text { are prioritized due to institutional } \\
\text { influence. }\end{array}$ \\
\hline $\begin{array}{l}\text { Belaya \& Hanf, } \\
2011 \\
\text { International } \\
\text { Business and } \\
\text { Management }\end{array}$ & $\begin{array}{l}\text { Power and } \\
\text { coordination } \\
\text { in supply chain } \\
\text { management }\end{array}$ & $\begin{array}{l}40 \text { semi-structured } \\
\text { in-depth telephone } \\
\text { interviews lasting } \\
\text { from } 15 \text { to } 60 \\
\text { minutes per } \\
\text { respondent }\end{array}$ & $\begin{array}{l}\text { Relations in supply chains are affected } \\
\text { by the quality of agricultural supplies; } \\
\text { Russian management style and } \\
\text { mentality; opportunism and absence } \\
\text { of trust; administrative barriers, } \\
\text { transport, logistics, and infrastructure. } \\
\text { Coercive or reward power might have } \\
\text { strong effects on coordination. }\end{array}$ \\
\hline $\begin{array}{l}\text { Puffer \& } \\
\text { McCarthy, } 2011 \\
\text { Academy of } \\
\text { Management } \\
\text { Perspectives }\end{array}$ & $\begin{array}{l}\text { Formal and } \\
\text { informal } \\
\text { institution } \\
\text { development as a } \\
\text { driver of business } \\
\text { development }\end{array}$ & Conceptual paper & $\begin{array}{l}\text { The present persistence of informal } \\
\text { institutions in the context of a formal } \\
\text { institutional void could dramatically } \\
\text { slow down Russia's economic } \\
\text { development and remain a source of } \\
\text { the unbalanced, corruption-ridden, } \\
\text { natural resource-based economy. }\end{array}$ \\
\hline
\end{tabular}

While the first mid-term results of transformation (Salmi, 2004; Ayios, 2003) were represented in earlier studies, the latest studies focus on the most recent changes in Russian interfirm relationship management (Smirnova et al., 2011; Belaya \& Hanf, 2011; Puffer \& McCarthy, 2011). Some of the earlier studies (e.g., Ayios, 2003) investigated internal transformation in the Russian economy and did acknowledge a "fundamental difference" (Ayios, 2003). The current culture of business relationships combines newly acquired competences and rules, with a "part preference for network-based business relationships using old ties and informal activi- ties" (Ayios, 2003). Specifically, the regulation of interfirm relationships is subject to the changing regulation of the economy on the whole, changes in the business environment, and the level of maturity of the managerial mentality of Russian businesses. Thus, despite the traditionally highly important role of interpersonal relations in the Russian economy (Salmi, 2004; Jansson, Johanson \& Ramström, 2007), the ongoing economic transformation is leading to a corresponding transformation in the principles, strategies, and regulating mechanisms of interfirm relationships. As the present study aims to expand the theory of interfirm relationships in 
the context of emerging markets, the second research question is as follows: RQ2: How has the Russian food market structure changed, including shifts in the balance of power of the main players?

New relationship building, instead of the previously existing planning economy, has required substantial investments of time, resources, and efforts, resulting in the mutual learning and development of decentralized and mutually adjusted planning capabilities (Johanson, 2007). Besides the very fact that the transition has supported the building of stronger managerial competences, existing research on Russian relationships and networks suggests switching from supplier to customer orientation (Deshpandé \& Farley, 2005). The transition to a market economy contributed to the development of interfirm interactions towards a relational approach. However, many industries, in which the production process involves diversified operations of the various companies, but which perform only certain functions, have not been comprehensively studied in Russia. In particular, one of these industries is agribusiness, in which the product creation process includes a lot of participants. And before agricultural goods reach the final customers, they are the subjects of trade in different B2B relationships.

Interfirm relationships in emerging markets are changing, and Russia is no exception. Russian companies have moved from personal relationships to interfirm relationships, and the understanding of the importance of interfirm relationships is evolving from year to year. However, despite this trend, the Russian food embargo modified the reality. Although the embargo was a special condition imposed on the Russian companies which were forced to adapt their functioning, it also served as a stimulus, triggering changes in interfirm relationships. Such conditions created a special context, and it is interesting to observe how companies reacted to that situation. This leads to the third research question, RQ3: Which criteria were implemented to manage interfirm relationships after the Russian food embargo?

\section{METHODOLOGY}

To achieve the objectives of the study through qualitative research, a semi-structured focus group was conducted. This method is usually used to gain new insights into topics that are not well understood. The choice of focus group as a method of qualitative research was made for the following reasons:

1. The Russian food embargo was established in 2014, and its long-term impact on Russian companies has not yet identified. Since then, however, Russian companies have taken strategic decisions concerning management tactics and interfirm relationships. Qualitative research methods are ideal for investigating these issues because communicating with staff who are making such decisions sheds light on the true situation firsthand. In addition, the focus group discussion could help identify any changes in interfirm interactions emerging since the introduction of the Russian food embargo.

2. Previous studies of Russian agricultural companies are quite narrow in scope (focusing on one industry, form of organization, or region only) and do not reflect the specificity of interfirm relationships in the industry. Therefore, the focus group was able to reveal how companies in Russian agribusiness had built relationships with their partners until 2014.

On the other hand, using a focus group as a qualitative research method helps in providing a description of the situation from different angles, as two sides are involved in the relationship process: producers and retailers. The focus group guide was formed in a way that enabled following the logic of the research questions. The guide was split into four sections with the aim of revealing the changes in relationship transformation:

o interaction with suppliers,

o identification of new suppliers,

- criteria for selecting suppliers,

o criteria for cooperation. 
The focus group comprised nine people, and discussions with its members were held in October 2015. In order to participate in the focus group, the respondents had to meet the following criteria: (1) work for a company in the Russian agribusiness sector as a retailer or producer, (2) hold a senior or middle-management position in the company operating in Russia, and (3) have more than 10 years' experience in management. Four respondents were employees of international retail chains operating in Russia (with a total market share of approximately 65 percent), while five worked for leading producers of consumer goods in Russia.

TABLE 3: Description of focus group participants

\begin{tabular}{|c|l|l|l|l|}
\hline No & \multicolumn{1}{|c|}{$\begin{array}{c}\text { Characteristics of the } \\
\text { company }\end{array}$} & $\begin{array}{l}\text { Producer } \\
\text { / Retailer }\end{array}$ & \multicolumn{1}{|c|}{ Position } & Work experience \\
\hline 1 & $\begin{array}{l}\text { one of the largest Russian sugar } \\
\text { producers }\end{array}$ & producer & CEO & more than 25 years \\
\hline 2 & $\begin{array}{l}\text { fully integrated agricultural } \\
\text { company }\end{array}$ & producer & CEO & 31 years \\
\hline 3 & $\begin{array}{l}\text { one of the largest Russian dairy } \\
\text { producers }\end{array}$ & producer & marketing director & about 16 years \\
\hline 4 & international retail chain & retailer & key account manager & more than 10 years \\
\hline 5 & international retail chain & retailer & new business director & about 10 years \\
\hline 6 & Russian federal retail chain & retailer & CEO & about 30 years \\
\hline 7 & $\begin{array}{l}\text { one of the largest Russian meat } \\
\text { producers }\end{array}$ & producer & marketing director & more than 19 years \\
\hline 8 & Russian federal retail chain & retailer & sales director & more than 15 years \\
\hline 9 & agricultural holding & producer & finance director & more than 30 years \\
\hline
\end{tabular}

Discussions with the focus group were recorded and subsequently transcribed. The study was conducted in Moscow, but, in geographical terms, it covered Moscow, St. Petersburg, Krasnodar, and Kirzhach. The participants were recruited at an industrial conference in Moscow, with focus group discussions conducted a day after the conference. First, the participants were asked to characterize interactions with their partners, highlighting the main changes in their relationships. Second, they were asked to describe why and how they sought new partners. Afterwards, the discussion shifted to the criteria participants used to attract and retain new partners.

The data collected were analyzed using content analysis and, on based on these constructs and sub-constructs, the main changes caused by the food embargo were identified.

Due to the fact that the study was conducted using a qualitative method, the results could not be extended to cover the entire Russian industrial market. However, the focus group enabled the authors of the study to increase our knowledge about the features characterizing the way in which Russian agribusiness companies were functioning in the given market circumstances.

\section{RESULTS AND DISCUSSION}

Since the focus group consisted of representatives of different agribusiness spheres, the study was able to investigate the situation from the diverse perspectives of retailers and manufacturers, providing important insights into the embargo's effects on the sample group's business. Firstly, we set out to establish how the food embargo affected the functioning of retailers, since their market power in the Russian economy has grown significantly in recent years and they have been able to dictate conditions to other participants in the entire value chain. 


\subsection{Retailers}

\section{Long-term interactions with suppliers.}

All the respondents agreed that retailers nowadays have a tendency to adjust their approach to interacting and working with suppliers in building sustainable value chains, as their presence in Russia's retail chains has demonstrated their increasing strength and prominence in the market. Despite the difficult political and economic situation in recent years, food retailers have shown positive growth rates, so they have not lost their dominant position in the relationships with suppliers. However, our study found that there is a clear focus on building long-term relationships. Companies tend to select suppliers that can serve as their sustainable partners for several years. None of the respondents noted an interest in individual transactions in "buyer-supplier" relationships. However, almost all of them agreed that the interaction with various agencies (e.g., research, advertising, branding agencies, etc.) could not be established as longterm partnerships. According to the respondents, there are some points restricting the attractiveness of partnerships with agencies:

o In the process of choosing an agency, a company should use a tender system;

- Considerable differences exist in the prices of various agencies;

- A high level of labor mobility in agencies (a person who is preparing your project can move to another company).

These reasons support the proposal that a suitable agency should be chosen by a company in each specific case. In order to build long-term relationships with suppliers, retailers should use tools helping them create and retain loyalty. This means that, in addition to the traditional financial methods of stimulating the development of interactions, retailers should use promotional activities, specialized programs, and other opportunities to "win" their partners.

According to the respondents, there are practices in Russia by which retailers offer assistance to their suppliers in training, raising the level of skills development, and in creating specialized schools for their staff. In addition, they strive to develop their partners by providing them with access to new technologies and scientific developments. Also, retailers in Russia have created loyalty programs aimed at offering additional bonuses in the case of long-term contracts. It is important to note that this is true not only of foreign but of Russian retailers as well. Thus, companies dealing in agricultural products in the Russian market tend to build loyal, longterm relationships with their partners, who use different marketing tools. Such partnerships can be viewed as a manifestation of the relational approach to marketing.

\section{New criteria for selecting suppliers.}

During the course of this research, it was revealed that the Russian food embargo affected the criteria imposed by retailers on their suppliers. After the food embargo was introduced, retail chains faced a difficult situation in which they had to address issues relating to the forbidden products they had bought before the food embargo. They also had to solve the problem of future supplies. As far as replenishing goods on the shelves is concerned, retail chains were forced to make concessions to suppliers in order not to lose their consumers. According to the participants of the focus group, during the first months after the introduction of the food embargo, retailers had to significantly simplify supplier requirements. As one of the respondents highlighted: "It was a forced measure to mitigate the criteria for Russian suppliers. Retailers were losing great amounts because of the embargo, and new costs were also possible due to empty shelves. Therefore, the Russian suppliers were very helpful."

In order to prevent a situation in which their shelves would stand empty, retail chains agreed to cooperate even with untested suppliers. As a result, the retailers were faced with unscrupulous partners who violated the terms and conditions of their supply contracts. Many retail chains were "dissatisfied" with the new suppli-

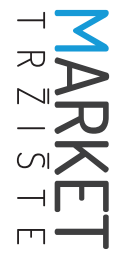




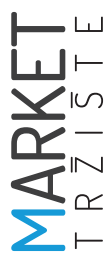

ers, so they were forced to seek alternative partners. Consequently, many retailers reconsidered their priorities and began to change the criteria according to which supplier selection would be conducted.

It has become a rule to consider that, in the process of selecting suppliers, retail chains are guided mainly by price and bonus indicators (Radaev, 2008). However, the focus group participants said that, after the introduction of the food embargo, the main criteria in selecting suppliers were reliability and the guarantee of uninterrupted supply. Retailers paid attention to the ability of potential partners to work in a turbulent environment and their ability to adapt to the changing conditions. However, it is difficult to estimate such characteristics in real time, which is why the historical reputation of a supplier was crucial. One of the respondents noted: "Undoubtedly, JIT (Just in time) is very important; no one guarantees correct and accurate deliveries. But it is more important for us how the supplier will act under extreme conditions. When choosing between two providers, we would rather select the one who tried to honestly fulfill their obligations in a difficult situation, even if, under normal conditions, this company was not always accurate."

With regard to promotional activities, the respondents reported a decrease in the importance of this characteristic for retailers when choosing potential partners. Retail chains found that the budgets of large international brands for product promotion exceed by far the budgets that Russian companies can afford. In addition, with a lot of new companies in the market, there are products which are still unknown to consumers. Therefore, the characteristics of promotion could create a restriction, which might prevent potential partnerships with Russian companies and with newcomers to the market. "Retailers show less care about advertising when selecting suppliers. Before the introduction of the food embargo, both package design and advertising were very important characteristics in the partnership. But today, package design and advertising are certainly a plus, but not a fundamental criterion."
New criteria, which retailers began to formulate when the food embargo was imposed, revealed the most important characteristics for functioning in a turbulent environment. For example, at the end of 2015, X5 Retail Group in Russia published new criteria for selecting suppliers. These are provided in Table 4.

TABLE 4: Criteria of X5 Retail Group for the selection of suppliers (Russia)

\begin{tabular}{|c|c|}
\hline Criteria & Description of criteria \\
\hline $\begin{array}{l}\text { Transparency } \\
\text { and } \\
\text { openness }\end{array}$ & $\begin{array}{l}\text { In the process of interacting } \\
\text { with suppliers, the company } \\
\text { provides them with access } \\
\text { to information about } \\
\text { the principles of supplier } \\
\text { selection, the draft supply } \\
\text { contract and other essential } \\
\text { information posted on the } \\
\text { company's official website. }\end{array}$ \\
\hline Privacy policy & $\begin{array}{l}\text { Guided by the principles of } \\
\text { transparency and openness } \\
\text { in relationships with suppliers, } \\
\text { the company recognizes } \\
\text { the right of the supplier to } \\
\text { the commercial secret and } \\
\text { confidentiality of information } \\
\text { provided. }\end{array}$ \\
\hline Efficiency & $\begin{array}{l}\text { Through its retail network, } \\
\text { the company seeks to } \\
\text { implement high-quality } \\
\text { products at economically } \\
\text { feasible prices by selecting the } \\
\text { most favorable conditions of } \\
\text { cooperation with suppliers. }\end{array}$ \\
\hline $\begin{array}{l}\text { Reasonable } \\
\text { foresight }\end{array}$ & $\begin{array}{l}\text { Insofar as this is feasible, the } \\
\text { company conducts an audit } \\
\text { of suppliers to ensure their } \\
\text { integrity and adherence to the } \\
\text { requirements of the legislation } \\
\text { of the Russian Federation. }\end{array}$ \\
\hline
\end{tabular}

Source: X5 Retail Group's contract with suppliers.

Although the criteria for selecting suppliers were formulated using rather fuzzy logic, there was clearly a shift toward reliability, illustrated 
by the presence of the criteria of openness and prudence. Thus, one of the most important criteria for retailers was the ability to change the conditions of supply and the ability to operate in a turbulent environment.

\section{Own production facilities.}

Continuous changes in the external environment, especially political factors, significantly influenced the choice of foreign suppliers. On the other hand, Russian suppliers did not always have the necessary qualities or capabilities required by retailers. All the participants of the focus group noted that any supplier, in one way or another, forces the retailer to adjust relationships with the chain as a whole. Due to the turbulent external environment, suppliers were switched quite often. Therefore, according to the respondents, a Russian retailer's interest in its own company's production facilities was justified.

While backward integration is not a new strategy for retailers in the Russian market, experience shows that this approach is rarely used. As a rule, retailers' own manufacture is limited to the store environment (for example, bakeries in supermarkets, where they make their own bread and sell it immediately). According to the participants of the focus group, as soon as the food embargo was imposed, retailers began to seek opportunities for establishing their own production facilities. Moreover, considering the need to create competitive products, companies started investing in research and technology development.

There are not many examples of retailers with their own production facilities in Russia. One of the most successful examples of such a business model is the "Magnit" retail chain, which has a greenhouse complex called "Green Line". Over an area of 40 ha, the retailer grows cucumbers, tomatoes, and salad crops (lettuce, dill, and parsley). This territory is not well developed yet, which is why the produce satisfies only a part of the retail network's demand.

Nowadays, we can see that other retail chains in Russia are opting for backward integration too.
Thus, the respondents suggest that this business model will expand actively in the years to come.

\subsection{Producers}

1. New suppliers.

The producers' search for new partners is related to the supplier not only in terms of product realization but also in terms of product creation, i.e., suppliers of raw materials. It is clear that the embargo created additional costs for companies. As one of the participants of the focus group highlighted: "Exploring something new is always fraught with certain risks and costs. And the relationship with a new supplier is a kind of 'Pandora's box,' with a broad array of additional threats."

The primary threat highlighted by the respondents is the fact that the process of interacting with a new supplier requires relationships to be built from scratch. This implies significant risks for producers of agricultural products, especially when such producers are not major companies. The respondents noted cooperation with a potential partner, such as a major Western company, would certainly be facilitated if it had a supply chain and a developed infrastructure in Russia. But, as a rule, vital suppliers from countries that are not subject to the embargo do not possess such resources; hence, building relationships with them would create a number of both tangible and intangible costs, for example, those related to time.

In addition, the production process of many manufacturers of agricultural goods requires very specific resources. These could be cover (such as forage) and basic products, e.g., seedlings, which are procured from foreign suppliers. The number of manufacturers of such specific products around the world is very limited. Therefore, understanding the "necessity" of such products for Russian companies, suppliers could increase prices or adjust the terms of their offers making them less favorable to Russian customers (compared with the conditions under which Russian companies collaborated with their previous partners). In this case, if the costs

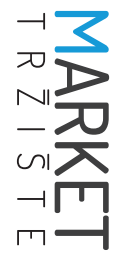


were sufficiently high, many companies would not be able to operate and would have to leave the market.

Overall, the participants of the focus group highlighted that the Russian producer market of agricultural goods is characterized by a high degree of fragmentation due to the great number of both large and small producers of similar products in the market. The embargo represents the greatest threat to small manufacturers in this context.

\section{Changes in quality characteristics of products.}

In recent years, healthy diet trends have become increasingly popular among Russian consumers. Ecological purity and the organic origin of products have become important criteria for choosing food. Adjusting to that trend, new retail formats have focused on producing "healthy and useful" agricultural products. Outlets for such products include, for example, multi-branded eco-markets, farm shops, organic markets, and others. Prior to 2014, organic or "eco-friendly" products were mostly of foreign origin. However, the embargo encouraged Russian producers to address the local gap for these products in the market and the range of related sellers. But the possibility of partnering required relevant suppliers to ensure that their products contain certain quality characteristics. And if, for example, there was no organization to define the criteria to be met by organic products in Russia, the conditions for the creation of ecologically pure products had to be clearly described.

Thus, many Russian producers started focusing their attention on the environmental implications and quality of their products in their bid to remain competitive. As the respondents noted, the embargo encouraged manufacturers to pay attention to the qualitative characteristics of their products. This was not only motivated by the absence of goods of foreign producers in the market, but also because state support and more frequent tests (compared with the pre-embargo period) carried out by Rospotrebnadzor (Federal Service for the Supervision of
Consumer Rights Protection and Human Welfare) encouraged producers to create competitive, high-quality products.

\section{New criteria for cooperation with sellers.}

As mentioned above, retailers gradually changed the criteria they used in the supplier selection process. In this regard, producers were forced to find ways to present and convey important information to retailers. The important role of branding was also brought into focus. Manufacturers began to pay attention to brands, accepting them as a way of conveying reputational characteristics. For many years, the creation of brands in agribusiness was perceived only as an expense, and the main function of product marketing - as perceived by the companies was the ability to differentiate their brand in a competitive environment. The fact that retailers began to pay attention to the reputational characteristics of their partners brought about the creation of brands in Russian agribusiness. As one participant of the focus group noted about food companies: "A well-established brand, clearly communicating the benefits of their products, undoubtedly proves the reliability of a partner."

After all, a company focused on branding would commit time and resources to the creation of a detailed image, which in turn meant that such an organization cared about its acceptance by different groups of stakeholders. The respondents also noted that this tendency was observed even among small or regional suppliers. Almost all the participants of the focus group identified branding as an effective tool to promote competitive advantages to their partners; also, they had no doubt that brands could help foster long-term partnerships with retailers and other partners throughout the value chain.

Therefore, it is obvious that both retailers and producers in Russian agribusiness are moving toward long-term relationships. We can see today that they have already used certain instruments applying an interactional approach. According to research conducted by Smirnova (Smirnova et al., 2011), orientation on long-term 
relationships is characterized by a higher level of perception of both monetary and non-monetary values. It is clear from our study that Russian agribusiness pays attention not only to the financial aspects of interactions but to intangible assets, such as reputation or brand, as well. Accordingly, and in connection with Smirnova's research, we can suppose that agricultural retailers and suppliers in Russia tend to build longterm relationships. This is why understanding and implementing relationship marketing techniques has become extremely important.

It should be noted that after the embargo was introduced, there was a tendency to formalize objective reliability indicators concerning suppliers, which was radically different from the situation existing a few years earlier (Belaya \& Hanf, 2011). The power of coercion or reward has certainly not disappeared, but the risk of being left without a buyer has led to the need to meet the stricter parameters imposed by retailers on their suppliers. As Jansson, Johanson, and Ramström (2007) mentioned, retailers' trust and patience are still important in their relationships with suppliers and are now maintained with concrete criteria. Accordingly, the trend of rigid informalization (Radaev, 2003) is being replaced by the formalization of rules for building relationships between partners. At the same time, this is reflected not only in cooperation and awareness of the importance of true supplier reliability but also in the need to justify it because, in the end, disrupted deliveries lead to empty shelves - a situation retailers sought to avoid at all costs in the first months after the embargo was imposed. At the same time, personal relationships between representatives of various companies undoubtedly still influence considerably the building of relationships between companies (Halinen \& Salmi, 2001).

However, this type of relationship proved to be untenable in the context of turbulent changes in the market, given the failure to maintain contractual agreements, as the respondents noted. Therefore, certainly, the role of personal relationships has not been neutralized but has weakened, since external effects and business efficiency lead to the paramount importance of reliability. On the other hand, the specifics of the Russian mentality and management style affecting relations (Belaya \& Hanf, 2011) are particularly relevant in interactions between foreign retailers and Russian food producers. At the same time, however, these characteristics are quite strongly differentiated, depending on the size of the company. After the introduction of the embargo, these features underwent a change, which began manifesting themselves first in larger companies. Representatives of international retailers in the research sample noted that the smaller the company, the more difficult it is to build formal relationships. Therefore, under the conditions of the embargo, small businesses were forced to adapt, which is already evident from the change in the criteria for the interfirm relationship with sellers.

Administrative barriers (Belaya \& Hanf, 2011) continue to affect the relationships among companies throughout the value chain. The forms of government support announced after the embargo was imposed were limited by bureaucratic procedures, significantly restricting the ability of companies to use them. On the other hand, the current situation may suggest deliberate support for a particular company and an increased level of corruption, as suggested by Salmi (2004). However, this course was not covered by the respondents in the discussion, so it is impossible to confirm or deny such occurrences with any certainty.

The issue of trust between suppliers and retailers remains a serious unresolved question. It can be said that the transfer of responsibility has the potential to positively affect the level of trust in some way, in contrast with assertions by Ayios (2003). In a transparent environment, there is a high level of volatility, and companies run the risk of transferring responsibility to counterparties. But this issue can have a positive impact on a relationship, given that the implementation of such activities increases the reliability of the partner and proves it. The example given in 


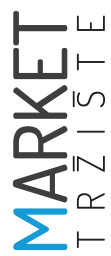

our research is the transfer of responsibility for meeting delivery deadlines to the manufacturer. Closer cooperation between the retailer and supplier and the establishment of a formalized relationship was mentioned.

Undoubtedly, the embargo has become a catalyst for changes in interfirm relationships among companies in the Russian market. Trends towards building long-term interactions and moving towards formalization were observed in the market before the food embargo was imposed. However, considering previous trends, we can say the implementation process is gradual when changes in related industries are manifested consistently, and various stakeholders are involved gradually (Salmi, 2004). Accordingly, if it were not for the embargo, changes in interfirm relations would not have occurred so quickly with the simultaneous inclusion of several stakeholders. Thus, the embargo accelerated trends that had begun already before it was imposed. But the changes concerning suppliers refer strictly to the Russian product embargo. In this context, the embargo acted as a "shock" to create new means of functioning in the market, pressuring suppliers and producers to re-create mature ways of surviving in the market. In this light, it is evident that the introduction of the Russian food embargo disrupted or broke up partnerships with current suppliers and put pressure on firms to seek and develop relationships with new suppliers.

As our study reveals, the main changes occurring in interfirm relationships in Russian agribusiness as a result of the food embargo imposed on the country include: (1) value chain changes; (2) changes in market structure; and (3) changes in the criteria for further cooperation between players. Focus group research has shed light on relations in the Russian food market, and the mixed nature of the sample provided the results on both the producer and the supplier side.

Future research directions include quantitative research aimed at testing the results of the study and revealing the current situation in the Russian food market. The first course of future research relates to evaluating the power of different groups of players in the Russian food market, including Russian and foreign producers and suppliers, and describing how the balance of market power has changed. Another course future quantitative research may take would consist an evaluation of the significance of the new partner selection criteria established during the first years of the Russian food embargo.

It should be noted that the changes in the value chain have been addressed for the first time in B2B marketing research. An analysis of the balance of power in the Russian context shows that the structure of the Russian food market is being challenged. Furthermore, changes in the criteria for interfirm relationships that apply to both suppliers and producers should be developed in order to communicate the partner's reliability. This paper provides researchers and practitioners with important insights into the specificities of relationships existing in Russia. This knowledge can help foreign companies entering the Russian market as well as Russian companies have a better understanding of the direction of changes occurring in turbulent circumstances.

The limitations of the current research are related primarily to the method used. While pointing to the main directions of change in Russian agribusiness caused by the food embargo, qualitative data obtained through the focus group are not statistically representative of Russian agribusiness as a whole. Additional research beyond our exploratory qualitative study is needed to quantitatively test the assumption and generalize the results.

\section{CONCLUSION}

The Russian market in agricultural products is a strategically important field from an economic and national point of view. Agribusiness not only employs a large portion of the labor force, but the development of this sector is also important because it contributes to food security and reduced dependence on imports. Today, the government is taking all possible measures to support companies involved in all spheres of agri- 
business on both micro and macro levels. There is no doubt that state support of agribusiness leads to positive results. These include helping to modernize the material and technical equipment of enterprises, develop new forms of partnerships (e.g., private-government partnerships), and increase the number of individual farmers.

However, as with all kinds of changes, these actions require that activities be adapted, new relationships formed, and the usual functioning principles adjusted. While retailers and manufacturers respond differently to government policy, a general tendency may be observed. The desire for long-term partnerships, the priority placed on such attributes as reliability and confidence in the company, and the company's reputation illustrate that Russian agribusiness companies are oriented toward a relational approach. Thus, we can conclude that interfirm relationships are increasingly important among agricultural companies in Russia. Finally, the specificity of marketing tools implemented for various stakeholders in the agribusiness value chain remains a question for future research.

\section{Acknowledgments}

The publication was prepared within the framework of the Academic Funding Program of the National Research University Higher School of Economics (HSE), grant № 19-01-025 for 20192020, and of the Russian Academic Excellence Project "5-100".

\section{References}

1. Achrol, R. S. (1997). Changes in the theory of interorganizational relations in marketing: Toward a network paradigm. Journal of the Academy of Marketing Science, 25(1), 56-71.

2. Achrol, R. S., \& Kotler, P. (1999). Marketing in the network economy. Journal of Marketing, 63(4), 146-163.

3. Anderson, J. C., Håkansson, H., \& Johanson, J. (1994). Dyadic business relationships within a business network context. Journal of Marketing, 58(4), 1-15.

4. Ayios, A. (2003). Competence and trust guardians as key elements of building trust in east-west joint ventures in Russia. Business Ethics: A European Review, 12(2), 190-202.

5. Balcilar, M., Kutan, A. M., \& Yaya, M. E. (2017). Testing the dependency theory on small island economies: The case of Cyprus. Economic Modelling, 61, 1-11.

6. Belaya, V., \& Hanf, J. H. (2011). Power as a Management Device for Networks. International Business \&Management, 2(1), 18-31.

7. Bolgova, E. (2017). For the two months of 2017, the volume of trade between Russia and China increased by almost 30\%. Available at: https://www.kp.ru/online/news/2677246/ (accessed July 12, 2018).

8. Campion, E. W., \& Morrissey, S. (2013). A different model—medical care in Cuba. New England Journal of Medicine, 368(4), 297-299.

9. Coulibaly, B. (2009). Effects of financial autarky and integration: The case of the South Africa embargo. Journal of International Money and Finance, 28(3), 454-478.

10. Cuellar, A. (2015). Preventing and treating child mental health problems. The Future of Children, 25(1), 111-134.

11. Davis, L., \& Engerman, S. (2003). History lessons: sanctions-neither war nor peace. Journal of Economic Perspectives, 17(2), 187-197.

12. Deshpandé, R., \& Farley, J. U. (2005). Thai Firms' Adaptations Following the Asian Economic Crisis: Market Orientation, Innovativeness and Organizational Culture Five Years After. Asian Journal of Marketing, 11(1), 140-145. 
13. Gordeev, V. (2016). Cuba gave a new assessment for the financial losses from the US embargo. Available at: https://www.rbc.ru/politics/10/09/2016/57d35f7a9a79474be42688ef (accessed on May 25, 2018).

14. Grosse, T. G. (2014). Geoeconomic relations between the EU and China: the lessons from the EU weapon embargo and from Galileo. Geopolitics, 19(1), 40-65.

15. Günçavdi, Ö., \& Küçükçifçi, S. (2009). Economic Growth Under Embargoes in North Cyprus: An Input-Output Analysis. Turkish Studies, 10(3), 365-392.

16. Håkansson, H., \& Ford, D. (2002). How should companies interact in business networks? Journal of Business Research, 55(2), 133-139.

17. Halinen, A., \& Salmi, A. (2001). Managing the informal side of business interaction: Personal contacts in the critical phases of business relationships. In Proceedings from the $17^{\text {th }}$ Annual IMP Conference, 9-11 September, Oslo (Norway).

18. Jansson, H., Johanson, M., \& Ramström, J. (2007). Institutions and business networks: A comparative analysis of the Chinese, Russian, and West European markets. Industrial Marketing Management, 36(7), 955-967.

19. Johanson, M. (2007). Networks in transition. 23rd IMP-conference, 30 August - Saturday 1 September, Manchester (UK).

20. National Research University "Higher School of Economics" (2016). Agroindustrial complex scientific and technological development forecast in the Russian Federation for the period up to 2030. Available at: https://www.hse.ru/data/2017/02/06/1167349282/Прогноз\%20научнотехнической\%20сферы.pdf (in Russian).

21. Patterson, R. (2013). EU sanctions on Iran: the European political context. Middle East Policy, 20(1), 135-146.

22. Puffer, S. M., \& McCarthy, D. J. (2011). Two decades of Russian business and management research: An institutional theory perspective. Academy of Management Perspectives, 25(2), 21-36.

23. Radaev, V. (2003). How trust is established in economic relationships when institutions and individuals are not trustworthy (the case of Russia). Collegium Budapest.

24. Radaev, V. (2008). Chto trebuyut roznichnye seti ot svoikh postavschikov: empiricheskii analiz [What Do Retailers Demand from Suppliers: Empirical Analysis]. Ekonomicheskaya Politika, 2, 58-82.

25. Sachdeva, G. (2014). EU-China and EU-India: A Tale of Two Strategic Partnerships. Strategic Analysis, 38(4), 427-431.

26. Salmi, A. (2004). Institutional change of business networks: Russian transition revisited. In Proceedings, 20 IMP conference, 2-4 September 2004, Copenhagen (Denmark).

27. Smirnova, M., Naudé, P., Henneberg, S. C., Mouzas, S., \& Kouchtch, S. P. (2011). The impact of market orientation on the development of relational capabilities and performance outcomes: The case of Russian industrial firms. Industrial Marketing Management, 40(1), 44-53.

28. Torbat, A. E. (2005). Impacts of the US trade and financial sanctions on Iran. World Economy, 28(3), 407-434.

29. Usova, A. (2014). Actual problems in system of strategic management of the agro-industrial enterprises of dairy specialization of agrarian and industrial complex. Ekonomiks, 3, 36-42.

30. Uzzi, B. (1997). Social structure and competition in interfirm networks: The paradox of embeddedness. Administrative Science Quarterly, 42(1), 35-67.

31. Wengle, S. (2016). The domestic effects of the Russian food embargo. Demokratizatsiya: Journal of Post-Soviet Democratization, 24(3), 281-289.

\section{Endnotes}

The tradable sector consists of the manufacturing and agricultural sectors.

2 Non-tradable economic activities include tourism, higher education, and other services.

3 Agriculture and manufacturing are the only two sectors of Northern Cyprus' economy allowing for the production of goods for international trade 